\title{
SSynthesis
}

International Scientific Conference of IT and Business-Related Research

\section{COLLECTION MANAGEMENT MODEL FOR CORPORATE CLIENTS IN THE SERBIAN BANKING SECTOR}

\author{
MODEL UPRAVLJANJA NAPLATOM POTRAŽIVANJA ZA KORPORATIVNE KLIJENTE \\ U BANKARSKOM SEKTORU SRBIJE
}

\author{
Lidija Barjaktarović1, Dragan Ilić2 , Marko Marković ${ }^{1}$ \\ ${ }^{1}$ Singidunum Univesity Belgrade, Faculty of Business in Belgrade, 32 Street Danijelova St., Belgrade, Serbia \\ ${ }^{2}$ BKF University of Applied Sciences Budapest, Nagy Lajos király útja 1-9., 1148 Budapest, Hungary; Banca Intesa a.d. Belgrade, Serbia
}

\begin{abstract}
:
Collection management is the key element of successful credit risk management. Therefore, successful collection management is one of the most important tasks of any bank. This paper analyses the results of collection management models applied in Erste bank a.d, Novi Sad and Banca Intesa a.d., Belgrade since 2010.

The main hypothesis is that good collection management model provides a satisfactory level of NPLs and bank profitability, which shall be further supported by this research. NPL of BI amounted to $6.67 \%$, while EB had NPLs amounted to $17.67 \%$, which is lower than the average NPL rate of the Serbian banking sector of 21.4\% (in 2013). Furthermore, ROE of BI was $8.7 \%$, while EB had ROE of $10.42 \%$, which is higher than the average ROE of $3.81 \%$ of the Serbian banking sector (in 2013). Finally, future research shall be directed towards comparing the results of both banks with the results of the parent banking groups in Austria and Italy i.e. the European Union.
\end{abstract}

\section{Key words:}

credit risk, NPL, ROE, Banca Intesa, Erste bank.

\section{Apstrakt:}

Naplata potraživanja predstavlja ključni element uspešnog upravljanja kreditnim rizikom. Shodno tome, uspešno upravljanje naplatom potraživanja je najvažniji zadatak svake poslovne banke. Predmet ovog rada su rezultati primene modela naplate potraživanja u Erste bank a.d. Novi Sad (EB) i Banca Intesi a.d. Beograd (BI) od 2010. godine. Osnovna hipoteza rada je da dobra naplata potraživanja obezbeđuje zadovoljavajući nivo rezervacija za problematične kredite i profitabilnost banke. Rezultati sprovedene analize u istraživanju govore u prilog istoj. NPL BI je na nivou od 6,67\%, dok je NPL EB u visini od $17,67 \%$, što je niže od proseka NPL-a bankarskog sektora Srbije - 21,4\% (2013.). Takođe, ROE BI je iznosio 8,7\% dok je ROE EB bio na nivou od 10,42\%, što je više od prosečnog ROE bankarskog sektora Srbije - 3,81\% (2013.). Buduća istraživanja će ići u pravcu poređenja ostvarenih rezultata obe lokalne banke sa rezultatima matičnih bankarskih grupa u Austriji i Italiji, odnosno Evropskoj uniji.

\section{Ključne reči:}

kreditni rizik, NPL, ROE, Banca Intesa, Erste banka.

\section{Acknowledgements:}

This Research Paper was part of the project "Advancing Serbia’s Competitiveness in the Process of EU Accession", No. 47028, for the period 2011-2015, which was financed by the Serbian Ministry of Education, Science and Technological Development.

\section{INTRODUCTION}

Credit risk is the probability that the bank will not be in a position to collect total receivables from its customers, i.e. principal amount and all related interest rates and fees. Having in mind the cause of the credit transaction, it is possible to list three types of credit risk: (1) default risk (exists at the moment of loan approval), (2) premium credit risk (exists at the moment of loan usage and has an impact on loan repayment issues) and (3) risk of worthiness of the credit rating (exists at the moment of loan repayment). It is important to emphasize that credit risk can be monitored in the banking book (critical threat to credit portfolio, which affects the banks in liquidity) and the bank's trading book (Barjaktarovic, 2013).

Collection management is crucial for credit risk management. Moreover, collection management has an impact on bank's profitability and all risk parameters, decrease of the new non-performing loan (NPL) portfolio and improvement of the quality of the credit portfolio. Thus, it is necessary to emphasize the considerable impact of collection management on the decrease of reservation (which can be booked in the profit and loss account or on the equity-based position), which has an impact on the increase of profitability or decrease of the equity (Barjaktarović, 2013; Barjaktarović et al., 2011).

The bank is successful provided that it can meet the following criteria: (1) volume of the newly approved loans and an increase of the credit portfolio in accordance with the defined targets, (2) bank profitability and (3) the level of non-performing loans. Therefore, we may conclude that the successful collection management is one of the most important tasks of the bank.

The subject of the analysis are the results of the collection management model (CMM) applied to the corporate credit portfolio of Erste bank a.d Novi Sad (EB) and Banca Intesa a.d Belgrade (BI). Both banks introduced CMM during the second part of 2010. Therefore, this research shall cover the period from 2010 to 2013.

The main research hypothesis is that good collection management model ensures the satisfactory level of NPLs and bank profitability. It means that those indicators are below the average of the Serbian banking sector. 
CMM model consists of: Aims, Organization, Architecture, Instruments, Control and Monitoring within the model (Barjaktarovic et al., 2011; Banca Intesa a.d. Belgrade, 2012). The paralel review of the common and different items in models is shown in Table 1.

Aims are the same for both banks.

Organization of the model covers classification of debtors and participants within the model. Both banks use delay days as the common criteria for this activity. However, they differ in terms of prime clasification of the customer: (1) Erste bank uses rating of the customer (as result of the internal credit rating tool); for the final segmentation of the customer in the portfolio, expert opinion is relevant (based on the individual assessment of risk management division of the bank);(2) Banca Intesa uses segmentation determined by the type of the customer (according to the achieved turnover, ownership structure and geographical presence). The main subjects in creditor-debtor relationship are creditors (banks) and debtors (companies).

Participants in both models are almost the same. The difference is the result of the internal organization. The crucial thing is that all involved departments should have established good cooperation.

Risk management division is responsible for individual credit risk assessment in the following segments: initial crediting, collection management and collateral management. The tasks of the risk management division include: (1) restructuring: business renewal or refinancing, monitoring of the problematic loans, watch lists, stress renewal or refinancing, (2) liquidation: collection from the bankruptcy, collection from the collateral, sale of business, sale of receivables, (3) reporting and analysis: delay reports, work-out reports, provisioning management, assistance in the budgeting process.

Arhitecture and Instruments are the same for both models.

Control and monitoring within the model differ for both banks. Erste bank divides credit customers in 3 zones according to the level of risk : (1) red zone - the most risky customers within the portfolio, (2) yellow zone - the zone of medium risk, (3) green zone - the zone of the low risk. After the corporate credit risk manager sends information to the responsible account manager concerning the customers who are potentially problematic in the future in order to organize the meeting with such customers and prepare proper strategy for the customers i.e. collection of the receivables. It practically means preparation of review application. Generally, the risk management division monitors credit portfolio on a permanent basis, but if they determine that it is necessary, they can monitor the credit risk on a particular customer i.e. loan.

Banca Intesa has permanent campaigns for target group of customers - PL or NPL. The parameters of the campaign are: Gross exposure included and Current provisions. Expected and

\begin{tabular}{|c|c|c|}
\hline Elements & Erste & Intesa \\
\hline Aims & \multicolumn{2}{|c|}{$\begin{array}{l}\text { 1) Regular servicing of the customers' credit commitments, } \\
\text { 2) Minimizing the delay in servicing credit commitments towards the bank, } \\
\text { 3) Minimizing the number of NPLs in credit portfolio. }\end{array}$} \\
\hline & $\begin{array}{l}\text { Rating of the customer and delay basket; } \\
\text { Corporate division, Risk management divi- } \\
\text { sion (Corporate credit risk management, } \\
\text { Collateral management and Collection man- } \\
\text { agement), Credit committee, Legal division } \\
\text { and Back office (credit administration). }\end{array}$ & $\begin{array}{l}\text { Segmentation of the customer and delay basket (cluster data); } \\
\text { Corporate division, Risk management division (Corporate credit risk } \\
\text { management, Collateral management and Collection management), } \\
\text { Work out, Legal division; }\end{array}$ \\
\hline $\begin{array}{l}\text { Organization } \\
\text { 1) Classification of } \\
\text { debtors } \\
\text { 2) Participants }\end{array}$ & \multicolumn{2}{|c|}{$\begin{array}{l}\text { PL and NPL clients are subject to control and monitoring within the collection management model. } \\
\text { The model includes two analyses: quantitative analysis and qualitative analysis. Quantitative analysis represents chang- } \\
\text { es that already appeared in the customer's business and may affect the regular loan repayment and core business of the } \\
\text { customer. All early warning signs can be categorized as follows: big changes in customer's behaviour, market data, daily } \\
\text { business issues and signs of fraud. } \\
\text { Qualitative analysis represents the portfolio analysis on the basis of historical data. Historical data can be internal (in- } \\
\text { ternal data base) and external (market data). Internal indicators include: days of delay, ratings, industry and t/o through } \\
\text { the account within the bank. External indicators include: account blockade, financial data (t/o, gross profit margin, } \\
\text { EBIT, net profit, total assets, equity, short-term loans, long-term loans, receivables, payables, inventories). }\end{array}$} \\
\hline Architecture & \multicolumn{2}{|c|}{$\begin{array}{l}\text { Creditors and debtors; } \\
\text { Collection management process for PL portfolio and NPL portfolio }\end{array}$} \\
\hline Instruments & \multicolumn{2}{|c|}{$\begin{array}{l}\text { Source of repayment can be cash flow from regular (core) business, i.e. primary source of repayment (CF1) and col- } \\
\text { lateral loan i.e. secondary source of repayment (CF2). }\end{array}$} \\
\hline $\begin{array}{l}\text { Control and } \\
\text { monitoring }\end{array}$ & $\begin{array}{l}\text { All credit customers of the bank are divided } \\
\text { in three zones according to the risk level: } \\
\text { 1) Red zone - the most risky customers of } \\
\text { the portfolio, } \\
\text { 2) Yellow zone - the zone of medium risk, } \\
\text { 3) Green zone - the zone of the low risk. }\end{array}$ & $\begin{array}{l}\text { Basic principle: Continuious improvement; Review credit collection } \\
\text { process; } \\
\text { Key initiatives for Corporate: } \\
\text { 1-90 days - Early due payment day management (PL) } \\
90-180 \text { days - Soft collection (NPL) } \\
90-180 \text { days - Rescheduling \& agreed sale of client non-core assets (NPL) } \\
180 \text { + days - Destressed restructuring (NPL) } \\
180 \text { + days - Legal execution (NPL); } \\
\text { The campaign consist of: target group of PL or NPL; campaign parameters } \\
\text { and the expected key drives; }\end{array}$ \\
\hline
\end{tabular}

Table 1. Review of CMM elements - Erste bank a.d Novi Sad and Banca Intesa a.d. Belgrade 
key drivers of campaignes are: (1)Provisions reaslied, (2) Provisions avoided and (3) NPL back to performing (Action plan for NPL customer is part of this phase)

Both banks use Basel II rules and internal rating for credit risk. The authors chose those banks because they were involved in introducing CMM in those banks.

Key indicators that are the subject of this analysis are: NPL (\%), CAR (Capital Adequacy Ratio), quality of credit portfolio and ROE (Return on Equity). NPL, CAR and ROE will be compared with an average of the Serbian banking sector. The quality of credit portfolio has the following baskets: Performing loans (PL), Past due loans, Substandard loans, Restructured loans and Doubtful loans (prescribed by official regulation). According to the offical data of both banks, performing loans, past due and substandard loans belong to the healthy part of the porfolio, which is collected within the period of 90 days.

The analysis is based on the official financial and annual reports of the banks, disclosure requirements for Pillar 3 of Basel II, supervisory report of the National bank of Serbia available on their official sites. The analysis covered the period from 2010 to 2013.

There is a difference in the quality of information announced in the official reports of the banks. Erste bank Serbia (EB) has a better and more transparent risk management report compared to Banca Intesa (BI) in terms of available data about the accepted risks. Furthermore, the diference is observed in customer segmentation in terms of the criteria used. At the same time, this is also the limitation of the analysis. The proposed indicators of the analysis are common for both banks i.e. are annouced in the annual reports of banks.

\section{RESULTS AND DISCUSSION}

Comparative analysis of both banks confirmed that they demonstrated better results in managing credit risk than the Serbian banking sector, since 2011. Moreover, both banks recorded an increase in credit portfolio, with the majority being granted to corporate customers. Furthermore, NPL and ROE are at a satisfactory level. CAR indicators of both banks are at the level of the Serbian banking sector. Finally, it can be concluded that BI introduced better CMM and had a lower level of NPLs than EB and the Serbian banking sector. The review of the key performance indicators of $\mathrm{BI}$ and $\mathrm{EB}$ is given in Table 2 and Figure 1 (Banca Intesa a.d. Belgrade, 2007-2013; Erste bank a.d. Novi Sad, 2007-2013; National Bank of Serbia, 2007-2013).

The analysis of the quality of corporate credit portfolio of both banks is at a satisfactory level (see Table 3). The majority of loans are in the category of healthy loans that are collected within the period of up to 90 days following the instalment date. Implemented CMM in both banks directly affected the quality of portfolio in 2011, where BI had a higher volume of restructured loans compared to EB. However, EB recorded higher volume of doubtful loans since 2010. So, this is the reason why BI had lower NPLs then EB during the period of analysis (Banca Intesa a.d. Belgrade, 2007-2013; Erste bank a.d. Novi Sad, 2007-2013).

Finally, we can conclude that the main research hypothesis is that good collection management model provides the satisfactory level of NPLs and bank profitability. NPL of BI amounted to $6.67 \%$, while EB had NPL of $17.67 \%$, which was lower than the Serbian banking sector with NPL of $21.4 \%$ (in 2013). Furthermore, ROE of BI amounted to $8.7 \%$, while EB had ROE of $10.42 \%$, which is higher than ROE of $3.81 \%$, which is the average of the Serbian banking sector (in 2013). However, it is important to emphasize that both implemented CMM enabled banks to develop an appropriate corporate credit portfolio structure.

\section{SUMMARY}

BI and EB introduced CMM in 2010 in accordance with their organization and type of customers. The aim was clear - to decrease NPLs and increase profitability. Model organization is different, due to a different group policy in terms of risk management and business organization. Architecture and instruments are the same. Control and monitoring within the system are organized in accordance with the internal procedures and policies. It is important to emphasize that both CMMs are good because they provide the satisfactory level of NPLs and

\begin{tabular}{|c|c|c|c|c|c|c|c|}
\hline Year/ Indicator & 2007 & 2008 & 2009 & 2010 & 2011 & 2012 & 2013 \\
\hline \multicolumn{8}{|l|}{ Credits } \\
\hline BI & 95718412 & 165524335 & 181075733 & 245087290 & 249337725 & 259550499 & 265535776 \\
\hline $\mathrm{EB}$ & 20836077 & 30049493 & 30220438 & 43808647 & 45952772 & 55648156 & 58211657 \\
\hline \multicolumn{8}{|l|}{ Corporate credits } \\
\hline $\mathrm{BI}$ & 47382411 & 69910679 & 104528993 & 152645637 & 155679648 & 159850548 & 153874556 \\
\hline EB & 13266623 & 17804152 & 19523177 & 30376031 & 39652445 & 39923646 & 41293619 \\
\hline \multicolumn{8}{|l|}{ NPL (\%) } \\
\hline $\mathrm{BI}$ & n.a. & n.a. & n.a. & 3.13 & 4.03 & 5.01 & 6.67 \\
\hline $\mathrm{EB}$ & 14.53 & 11.43 & 13.65 & 11.49 & 13.97 & 14.46 & 17.67 \\
\hline Serbian banking sector & 11.3 & 11.3 & 15.7 & 16.9 & 19 & 18.6 & 21.4 \\
\hline \multicolumn{8}{|l|}{ ROE (\%) } \\
\hline $\mathrm{BI}$ & 11.79 & 14.59 & 13.41 & 14.76 & 13.29 & 11.44 & 8.7 \\
\hline EB & 1.7 & 3.17 & 3.58 & 3.13 & 7.76 & 12.3 & 10.42 \\
\hline Serbian banking sector & 9.28 & 9.3 & 4.6 & 5.4 & 0.24 & 2.05 & 3.81 \\
\hline \multicolumn{8}{|l|}{ CAR (\%) } \\
\hline $\mathrm{BI}$ & 24.31 & 18.79 & 17.67 & 18.62 & 16.86 & 19.79 & 19.91 \\
\hline $\mathrm{EB}$ & 40.39 & 26.58 & 26.06 & 17.63 & 24.37 & 21.34 & 20.95 \\
\hline Serbian banking sector & 27.9 & 21.9 & 21.44 & 19.91 & 19.11 & 19.87 & 20.9 \\
\hline
\end{tabular}

Table 2. Key performance indicators of BI and EB in the period from 2007 until 2013 (in 000 RSD, \%) 
Banca Intesa Belgrade

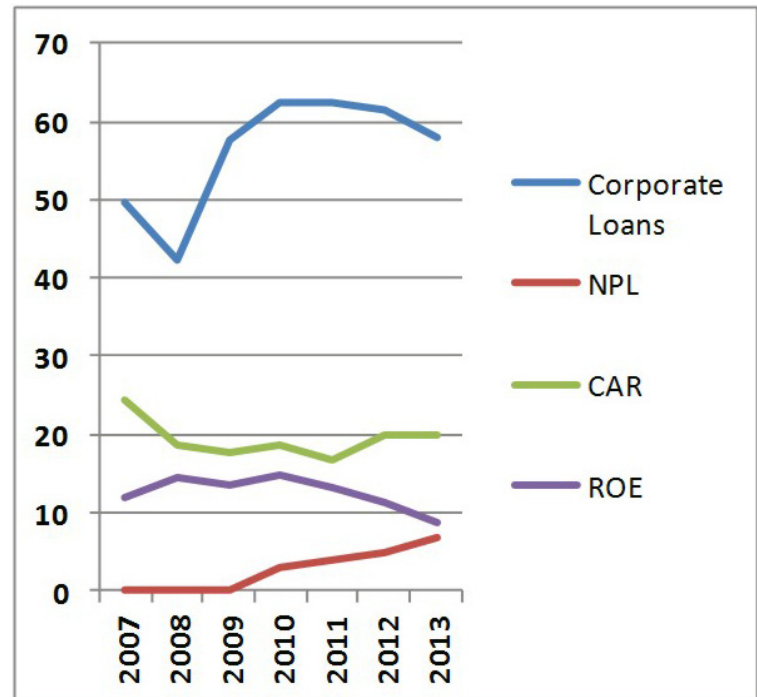

Erste bank Novi Sad

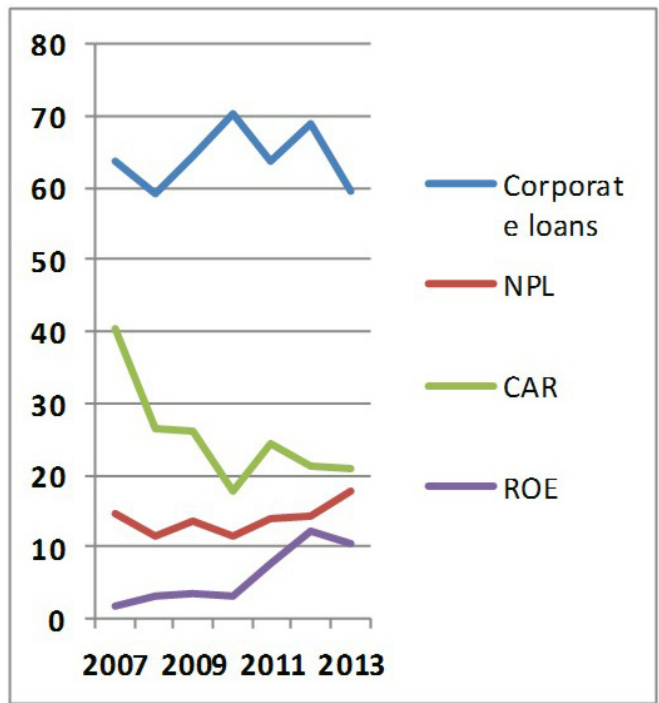

Figure 1. Key performance indicators of BI and EB in the period from 2007 to 2013 (\%)

\begin{tabular}{|c|c|c|c|c|c|c|c|}
\hline Year / Indicator & 2007 & 2008 & 2009 & 2010 & 2011 & 2012 & 2013 \\
\hline \multicolumn{8}{|l|}{ Performing loans } \\
\hline BI & 52.93 & 79.9 & 67.29 & 69.26 & 70.67 & 87.48 & 50.46 \\
\hline EB & 36.43 & 86.75 & 78.27 & 55.86 & 32.47 & 50.51 & 44.87 \\
\hline \multicolumn{8}{|l|}{ Past due loans } \\
\hline BI & 43.19 & 19.88 & 20.51 & 16.48 & 14.88 & 0.34 & 28.7 \\
\hline $\mathrm{EB}$ & 59.62 & 12.26 & 21.29 & 28.61 & 44.17 & 32.57 & 34 \\
\hline \multicolumn{8}{|l|}{ Substandard loans } \\
\hline BI & 0 & 0 & 0 & 6.84 & 4.34 & 4.48 & 0 \\
\hline $\mathrm{EB}$ & 0 & 0 & 0 & 0.4 & 5.29 & 1.57 & 0 \\
\hline \multicolumn{8}{|l|}{ Restructured loans } \\
\hline BI & 3.88 & 0.22 & 12.2 & 7.42 & 10.11 & 0.74 & 3.15 \\
\hline $\mathrm{EB}$ & 3.95 & 0.99 & 0.44 & 4.63 & 9.4 & 4.29 & 4.89 \\
\hline \multicolumn{8}{|l|}{ Doubtful loans } \\
\hline $\mathrm{BI}$ & 0 & 0 & 0 & 0 & 0 & 6.96 & 17.69 \\
\hline $\mathrm{EB}$ & 0 & 0 & 0 & 10.5 & 8.67 & 11.06 & 16.24 \\
\hline Total & 100 & 100 & 100 & 100 & 100 & 100 & 100 \\
\hline
\end{tabular}

Table 3 Quality of corporate credit portfolio BI and EB during the period from 2007 until 2013 (\%):

Source: Barjatarović (2013) and Barjaktarović et al. (2011)

profitability of banks. BI and EB demonstrated better results in managing credit risk than the Serbian banking sector, during the period from 2010 to 2013 .

\section{REFERENCES}

Barjaktarović, L. (2013). Risk management. Belgrade: University Singidunum.

Barjaktarović, L., Popovčić-Avrić, S., \& Đenić, M. (2011). Collection management as curtail part of credit risk management during the crisis. 8th AFE 2011 Conference, 30 ${ }^{\text {th }}$ June to $2^{\text {nd }}$ July 2011 (pp. 182-191). Samos, Greece: Research and Training Institute of the East Aegean (INEAG).
Banca Intesa a.d. Belgrade. Annual reports and Disclosure of data and information ( $3^{\text {rd }}$ Pillar of Basel II) for the period of 2007 to 2013. Retrieved February 02, 2015, from www. bancaintesabeograd.rs

Banca Intesa a.d. Belgrade. Radically strengthen Problem \& Deteriorated loans management within the Group 2012. Retrieved February 02, 2015, from www.bancaintesabeograd.rs

Erste Bank a.d. Novi Sad. Annual reports and Disclosure of data and information ( $3^{\text {rd }}$ Pillar of Basel II) of Erste Bank a.d. Novi Sad for the period of 2007 to 2013. Retrieved February 02, 2015, from www.erstebank.rs

National Bank of Serbia. Quarterly reports on Performance of Serbian banking sector in the period of 2007 to 2013. Retrieved February 02, 2015, from www.nbs.rs 